\title{
Penggunaan Alat Peraga pada Mata Pelajaran IPA sebagai Upaya Meningkatkan Hasil Belajar Siswa Kelas IV SD Negeri 06 Karang Tinggi
}

\author{
Seprianty \\ SDN 06 Karang Tinggi, Bengkulu Tengah \\ seprianty.limun@gmail.com
}

\begin{abstract}
Abstrak
Rendahnya hasil belajar siswa kelas IV SDN 06 Karang Tinggi disebabkan karena kurangnya keterlibatan siswa secara langsung dalam proses pembelajaran. Hal ini dapat dilihat dari 28 siswa hanya 9 orang siswa yang mencapai tingkat penguasaan materi $70 \%$ keatas terutama pada mata pelajaran IPA. Ditinjau dari pembelajaran IPA dibutuhkan suatu sikap dan teeori yang relevan terutama dalam mempersiapkan dan menggunakan media alat peraga. Tujua penelitian ini adalah untuk meningkatkan prestasi belajar siswa dengan menggunakan alat peraga IPA pada kelas IV SDN 06 Karang tinggi. Subjek penelitian adalah siswa berjumlah 28 orang, sumber data penelitian diperoleh dari data kualitatif berupa data hasil observasi aktivitas guru dan siswa serta data kuantitatif berupa data tes hasil belajar siswa. Hasil penelitian siklus I diperoleh siswa yang tuntas secara individu sebanyak 9 siswa dari 28 siswa dengan ketuntasan klasikal sebesar 32,2\%. Sedangkan hasil penelitian siklus II mengalami peningkatan dengan jumlah siswa yang tuntas secara individu sebanyak 15 siswa dari 28 orang siswa yang mengikuti pembelajaran dengan persentase ketuntasan klasikal sebesar $53,6 \%$. Hasil penelitian siklus III menunjukkan peningkatan ketuntasan siswa sebanyak 24 siswa dengan persentase ketuntasan klasikal sebesar 85,8\%.Berdasarkan hasil penelitian tersebut, pembelajaran menggunakan alat peraga IPA dapat meningkatkan hasil belajar siswa kelas IV di SDN 06 Karang Tinggi.
\end{abstract}

Kata Kunci : Alat Peraga, Hasil Belajar, IPA

\section{Pendahuluan}

Mengingat pendidikan merupakan upaya menyiapkan siswa menghadapi masa depan perubahan masyarakat yang sedemikian pesat. Terutama dalam ilmu pengetahuan dan Teknologi maka pengembangan pembelajaran haruslah berlandaskan Ilmu Pengetahuan dan Teknologi.

IPA adalah pengetahuan yang sistematis dan tersusun secara teratur, berlaku umum, dan berupa kumpulan data hasil observasi dan eksperimen (Depdiknas, 2003:4). Upaya guru untuk meningkatkan prestasi siswa dalam kegiatan pembelajaran harus ditempuh guru. Proses pembelajaran yang dilakukan oleh guru mampu menarik perhatian para siswa. Proses belajar mengajar yang tidak menarik dapat mengakibatkankejebuhan pada diri siswa. Bila ini terjadi, sudah pasti prestasi 
siswa tidak dapat ditingkatkan. Untuk dapat meningkatkan prestasi belajar siswa, maka guru harus merubah proses belajar mengajarnya, dari proses yang menjenuhkan menjadi proses belajar mengajar yang menarik bagi siswanya.

Upaya untuk meningkatkan prestasi sudah banyak dilakukan oleh guru namun hasilnya belum menunjukkan peningkatan yang berarti, bahkan dapat dikatakan masih berjalan di tempat. Dari hasil penelitian penulis tentang masalah di atas ternyata yang menjadi kendala adalah penggunaan metode dan media pembelajaran yang kurang tepat. Secara umum pengertian alat peraga adalah benda atau alat-alat yang diperlukan untuk melaksanakan kegiatan pembelajaran. Alat peraga adalah seperangkat benda konkrit yang dirancang, dibuat atau disusun secara sengaja yang digunakan untuk membantu menanamkan atau mengembangkan konsep-konsep atau prinsip-prinsip dalam pembelajaran. Alat peraga merupakan media pembelajaran yang mengandung atau membawakan ciri-ciri dari konsep yang dipelajari (Sudjana, 2008:90).

Alat peraga dalam proses pembelajaran memegang peranan penting sebagai alat bantu untuk proses pembelajaran yang efektif. Alat bantu pembelajaran adalah perlengkapan yang menyajikan satuan-satuan pengetahuan melalui stimulasi pendengaran, penglihatan, atau keduanya untuk membantu pembelajaran (Kochhar, 2008:214). Dari nilai rata-rata tes formatif kelas IV SDN 06 Karang tinggi, dari 28 siswa hanya 9 orang yang dapat mencapai tingkat penguasaan materi $70 \%$.

Mengingat pentingnya alat peraga/media pembelajaran dalam meningkatkan mutu pendidikan, guru dituntut untuk menguasai keterampilan memilih, mengembangkan dan menggunakan alat peraga/media yang sesuai dengan konsep yang dibahas/diajarkan.Adapun tujuan yang ingin dicapai dalam penelitian ini adalah untuk meningkatkan hasil belajar siswa dengan menggunakan alat peraga pada mata pelajaran IPA di kelas IV SDN 06 Karang Tinggi, Bengkulu Tengah.

\section{Metode}

Penelitian ini menggunakan metode Penelitian Tindakan Kelas (PTK). Penelitian Tindakan Kelas (PTK) merupakan salah satu upaya guru atau praktisi pendidikan uji coba inovasi pembelajaran dalam bentuk berbagai kegiatan yang dilakukan untuk memperbaiki atau meningkatkan mutu pembelajaran di kelas (Arikunto, 2010).

Desain Penelitian dalam penelitian ini Desain penelitian ini bersifat siklus dan lebih menekankan pada penelitian tindakan berulang. Penelitian ini dilakukan selama 3 siklus.Tiap siklus dilaksanakan dengan perubahan-perubahan ke arah peningkatan hasil belajar siswa. Desain penelitian yang digunakan dalam penelitian ini menggunakan desain penelitian Kemmis dan Mc Taggart yang merupakan pengembangan dari model Kurt Lewin. Dalam perencanaannya, kemmis menggunakan system spiral refleksi diri yang dimulai dengan rencana (planning), tindakan (acting), pengamatan (observing), refleksi (reflecting) dan perencanaan kembali yang merupakan dasar untuk suatu ancang-ancang pemecahan permasalahan. Pola dasar model PTK menurut Kemmis dan Mc. Taggart sebagai berikut. 


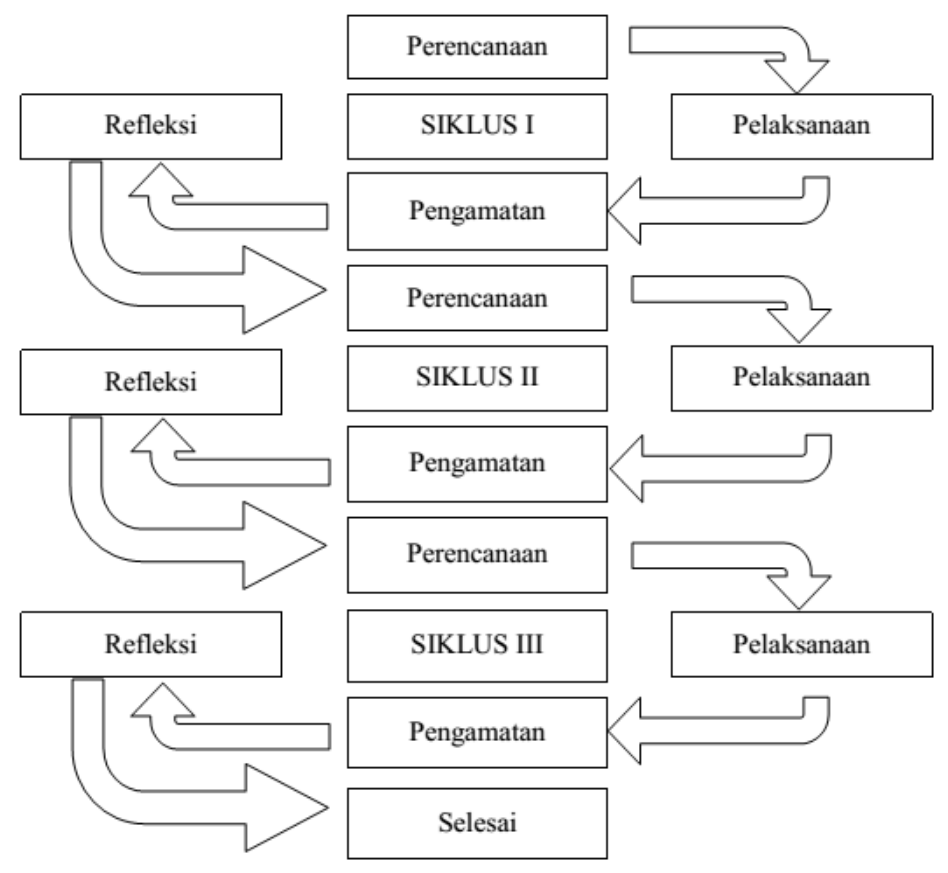

Gambar 1. Alur pelaksanaan Penelitian Tindakan Kelas (Arikunto, 2006).

Penelitian dilaksanakan pada tanggal 14- 28 oktober 2017 di kelas IV SDN 06 Karang Tinggi, Bengkulu Tengah. Sampel menurut Arikunto (1998) sebagian atau wakil populasi yang diteliti. Selanjutnya Arikunto (1998) memberikan penjelasan sebagai berikut: Apabila subyek kurang dari 100, lebih baik diambil semua sehingga penelitiannya merupakan penelitian populasi. Maka ditetapkan jumlah sampel dalampenelitian ini adalah 28 orang.

Menganalisis data merupakan cara yang digunakan peneliti untuk menguraikan data yang diperoleh dari penilitiansupaya dapat dipahami oleh semuanya bukan hanya oleh yang meneliti saja, tetapi juga oleh orang lain yang ingin mengetahui hasil penelitian yang telah dilaksanakan. Pada tahap ini dilakukan analisis untuk mengetahui sejauh mana tindakan yang sudah dilakukan pada setiap siklus, sehingga dapat dijadikan sebagai bahan pertimbangan untuk diperbaiki pada tindakan siklus selanjutnya yang akan dilaksanakan.

Menurut Arikunto dalam Ari (2016: 120) menyatakan bahwaanalisis data adalah proses pengorganisasian dan mengurutkan data kedalam pola, kategori dan satuan uraian dasar sehingga dapat ditemukan tema dan dapat dirumuskan hipotesis kerja seperti yang disarankan oleh data. Setelah analisis selesai, maka tahap selanjutnya adalah refleksi, refleksi pada prinsipnya mencakup kegiatan analisis, interpretasi dan evaluasi alat informasi yang diperoleh dari kegiatan observasi.

Data yang terkumpul diinterpretasi, sehingga dapat segera diketahui keberhasilan pencapaian tujuan dan tindakan yang telah dilakukan. Interpretasi hasil disusun langkah-langkah berikutnya dalam pelaksanaan tindakan dalamskenario pembelajaran disesuaikan dengan analisis data yang terkumpul untuk perbaikan pada siklus selanjutnya.Analisis data pada penelitian ini dilakukan secara kualitatif dan kuantitatif (statistik) sederhana.

Hasil dari tes didapatkan dengan berbagai cara yaitu dengan pretest dan posttest yang berisi soal essayyang harus dikerjakan oleh siswa sebelum pembelajaran dan 
sesudah pembelajaran. Setiap satu soal jika benar diberi bobot 20 jika siswa dapat mengerjakan semua soal dengan benar maka siswa mendapat nilai 100 .

1) Menghitung rata-rata

Rumus untuk menghitung rata - rata:

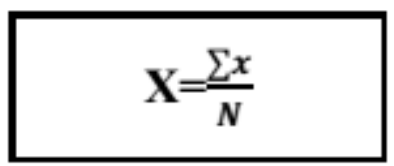

Sumber : Sudjana, 1990.

Keterangan :

$\mathrm{X}=$ Nilai Rata-Rata

$\sum \mathrm{X}^{\mathrm{i}} \quad=$ Jumlah seluruh skor

$\mathrm{N}=$ Banyak siswa yang memiliki skor

2) Ketercapaian Pembelajaran

Untuk menghitung persentase hasil siklus, dilakukan dengan perhitungan persentase menggunan rumus

$$
\mathrm{KB}=\frac{N s}{N} X 100 \%
$$

Sumber : Purwoko, 2001

Keterangan :

$\mathrm{Kb} \quad=$ Ketuntasan Belajar

$\mathrm{N}=$ Jumlah siswa yang mendapatkan nilai $\leq 70$

$\mathrm{N}=$ Jumlah siswa

Agar data tingkat ketercapaian pembelajaran yang diperoleh mudah untuk dilihat tingkat keberhasilannya, maka semua hasil yang diperoleh dikonversikan kedalam beberapa kategori sebagai berikut:

Tabel 1. Kriteria Penilaian Hasil Belajar Siswa

\begin{tabular}{|c|c|}
\hline Kriteria & Nilai \\
\hline Sangat Baik & $89<\mathrm{A} \leq 100$ \\
\hline Baik & $79<\mathrm{B} \leq 89$ \\
\hline Cukup & $70<\mathrm{C} \leq 79$ \\
\hline Perlu Bimbingan & $\mathrm{D}<70$ \\
\hline
\end{tabular}

\section{Hasil}

\section{Siklus 1}

Pada siklus I, jumlah siswa yang tuntas hanya berjumlah 9 dari 28 siswa dengan persentase ketuntasan klasikal sebesar 32,2\%. Berdasarkan hasil belajar siswa pada siklus I terdapat kelemahan-kelemahan, diantaranya

1. Adanya siswa yang belum toleransi kepada anggota kelompoknya. Hal tersebut dapat dilihat pada saat proses pembelajaran siswa yang paham tidak mau menjelaskan kepada siswa yang belum paham dalam setiap kelompok. 
2. Sikap siswa dalam kelompok yang menunjukkan kerja sama yang baik dan sikap siswa yang belum ada keseriusan dalam kelompok. Hal tersebut dapat dilihat siswa main - main saat diskusi kelompok.

3. Siswa dapat bekerjasama dalam kelompok dengan baik, siswa bergurau, tidak serius, belum ada kerja sama yang menonjol dalam kelompok.

Langkah-Langkah Revisi :

1. Menekankan kepada siswa yang sudah paham tentang materi untuk mengajari temannya yang belum paham dan mengajak siswa untuk lebih aktif dalam kerja sama kelompok.

2. Guru Membagi kelompok secara heterogen. Siswa yang pandaidikelompokkan dengan siswa yang masih belum paham mengenai materi.

3. Guru akan lebih membimbing kerja sama siswa pada saat siswa mengerjakan tugas yang diberikan.

4. Menekankan kepada siswa untuk meperhatikan persentase kelompok lain dengan seksama dan memberikan argumen terhadap persentase teman jika hasilnya tidak tepat.

\section{Siklus II}

Pada siklus II, jumlah siswa yang tuntas hanya berjumlah 15 dari 28 siswa dengan persentase ketuntasan klasikal sebesar 53,6\%. Berdasarkan hasil belajar siswa pada siklus I terdapat kelemahan-kelemahan, diantaranya :

1. Siswa dapat bekerjasama dalam kelompok, hanya sebagian siswa yang main main, bergurau, tidak serius, sehingga pada saat nomornya dipanggil siswa tersebut tidak bisa mempersentasekan dengan maksimal .

2. Siswa sudah mulai dapat memberikan argumen terhadap hasil diskusi kelompok lain, dan hanya sebagian siswa belum memberikan argumen tehadap kelompok lainkarena tidak memperhatikan persentase teman dengan seksama.

Langkah Revisi :

1. Lebih memotivasi siswa untuk lebih serius lagi dalam berdiskusi kelompok dan mengikuti tahapan - tahapan kegiatan pembelajaran.

2. Memberikan reward bagi siswa yang memberikan argumen terhadap hasil diskusi teman akan mendapatkan nilai tinggi.

\section{Siklus II}

Pada siklus III, jumlah siswa yang tuntas hanya berjumlah 24 dari 28 siswa dengan persentase ketuntasan klasikal sebesar $85,8 \% \%$. Dalam siklus III, terlihat kegiatan pembelajaran menggunakan alat bantu Peraga pada mata pelajaran IPA menunjukkan peningkatan.

\section{Pembahasan}

Hasil penelitian siklus I diperoleh siswa yang tuntas secara individu sebanyak 9 siswa dari 28 siswa dengan ketuntasan klasikal sebesar 32,2\%. Adapun aspek pengamatan yang termasuk dalam kategori cukup dan kurang pada aktivitas guru siklus I antara lain : (1) Guru sudah memberikan apersepsi kepada siswa tetapi belum maksimal, karena dalam memberikan apersepsi sesuai dengan materi tetapi guru tidak memotivasi siswa. Menurut Winarni (2009: 113) dalam pandangan Inquiri keberhasilan belajar bukan hanya bergantung pada lingkungan atau kondisi belajar, tetapi juga pada pengetahuan awal siswa, (2) Guru sudah memberikan kesempatan kepada siswa untuk berpikirsecara individu tapi guru hanya memberikan 1-3 menit untuk memikirkan jawaban atas pertanyaan yang diberikan oleh guru. Menurut Trianto (2009: 166) TPS mempersiakan peserta didik pada situasi untuk melakukan pecahan masalah dengan berpikir secara individu agar siswa lebih memahai pembelajaran. (3) Guru sudah membimbing siswa dalam 
menyimpulkan materi tapi guru hanya disebutkan dan kurang dapat menjawab pertanyaan siswa.

Sedangkan hasil penelitian siklus II mengalami peningkatan dengan jumlah siswa yang tuntas secara individu sebanyak 15 siswa dari 28 orang siswa yang mengikuti pembelajaran dengan persentase ketuntasan klasikal sebesar 53,6 \%.

Pada siklus II, terjadi peningkatan persentase ketuntasan belajar mahasiswa. Adanya peningkatan persentase ketuntasan belajar ini dikarenakan adanya upaya dosen yang lebih mengoptimalkan kegiatan pembelajaran yang erat kaitannya dengan situasi dan konteks kehidupan sehari-hari, sehingga mahasiswa mampu melakukan investigasi dan juga mengeksplorasi pengetahuannya.

Hasil penelitian siklus III menunjukkan peningkatan ketuntasan siswa sebanyak 24 siswa dengan persentase ketuntasan klasikal sebesar 85,8\%. Berdasarkan hasil penelitian tersebut, pembelajaran menggunakan alat peraga IPA dapat meningkatkan hasil belajar siswa kelas IV di SDN 06 Karang Tinggi.

Menurut Wilcox (2001) yang mengungkapkan bahwasanya pembelajaran dengan penemuan siswa didorong untuk belajar sebagian besar melalui keterlibatan aktif mereka sendiri dengan konsep-konsep dan prinsipprinsip dan guru mendorong siswa untuk memiliki pengalaman dan melakukanpercobaan yang memungkinkan mereka menemukan prinsip-prinsip untuk diri mereka sendiri.

Penggunaan alat peraga pada proses pembelajaran menempatkan siswa menjadi subjek pembelajaran (Student Centered Learning) bukan sebagai objek pembelajaran sehingga pembelajaran tidak hanya di dominasi oleh guru tetapi memberikan kesempatan kepada siswa agar untuk terlibat langsung dalam kegiatan tersebut. Serta dapat menimbulkan rasa kekeluargaan dan kebersamaan antar siswa sehingga siswa dapat bersosialisasi dengan temannya pada saat proses pembelajaran berlangsung.

\section{Kesimpulan}

Berdasarkan hasil analisis data yang diperoleh selama pelaksanaan tindakan Siklus I, Siklus II dan Siklus III, maka dapat disimpulkan bahwa penggunaan alat peraga pada Mata Pelajaran IPA dapat meningkatkan hasil belajar siswa kelas IV di SDN 06 Karang Tinggi. Hal ini dapat dilihat dari analisis data selama pelaksanaan tindakan Siklus I,Siklus II dan Siklus III. Pada siklus I ketuntasan belajar siswa secara klasikal sebesar 32,2 \%, pada siklus II ketuntasan belajar siswa secara klasikal sebesar 53,6 \% dan siklus III sebesar 85,8 \%.

\section{Referensi}

Agung, P. (2001). Panduan Penelitian PTK. Semarang : Unnes Press.Aliansyah, M. (2012) Penerapan Metode Demonstrasi Untuk Meningkatkan

Arikunto, S. 2006. Metode Penelitian Kualitatif. Jakarta: Bumi Aksara

Arikunto, S. 2010. Prosedur Penelitian Suatu Pendekatan Praktik. Jakarta:Rineka Cipta.

Arikunto, S. 1998. Prosuder Penelitian Suatu Pendekatan Praktek. Jakarta: PT. Rineka Cipta. 
Depdiknas. (2003). Kurikulum 2004, Standar Kompetensi Mata Pelajaran Sains Sekolah Dasar dan MI. Jakarta: Depdiknas.

Kochlar, S.K. 2008. Pembelajaran Sejarah. Jakarta: Grasindo

Sudjana, N. 1990. Teori-teori Belajar Untuk Pengajaran. Bandung: Fakultas Ekonomi UI.

Sudjana, N. 2008. Penilaian Hasil Proses Belajar Mengajar. Bandung: PT Remaja Rosdakarya.

Trianto, 2007. Model-Model Pembelajaran Inovatif Berorientasi Konstruktivistik.Jakarta : Prestasi Pustaka.

Winarni, E.W, Harmini, S. 2011. Matematika untuk PGSD. Bandung: Remaja Rosdakarya.

Wilcox, L. 2001. Personality Psikoterapi. Perbandingan dan Praktik Bimbingan dan Konseling Psikoterapi Kepribadian; Yogyakarta: ircisod. 